\title{
Intertekstualiteit en oorinterpretasie: Verwysings na Genesis 28:12 in Johannes 1:51?
}

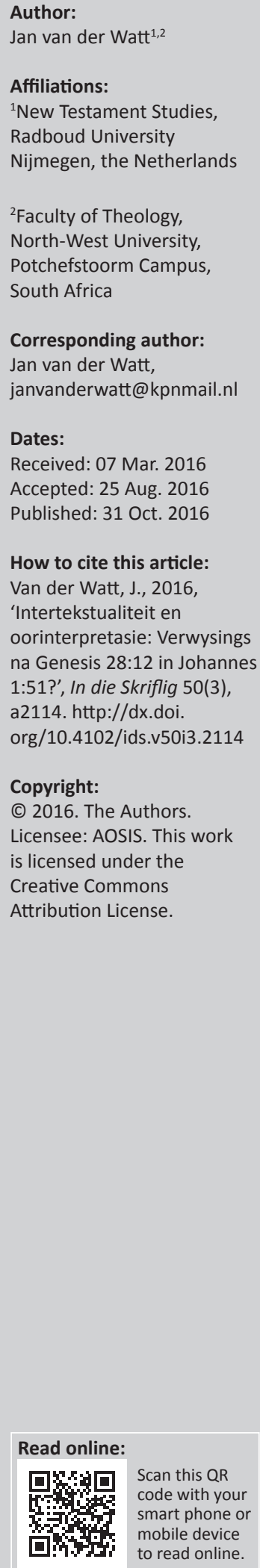

Intertextuality and over-interpretation: References to Genesis 28:12 in John 1:51? The aim of this article is to illustrate the dangers of over-interpretation when dealing with intertextual relations between texts, especially when allusion is assumed. Interpretations of the allusion to Genesis 28:12 in John 1:51 of the angels ascending and descending on Jacob are used as illustration of the measure of over-interpretation that is prevalent in current academic discussions, especially related to John. A close reading of John 1:51 is first made in order to establish the confines of the text. A brief survey of different interpretations of John 1:51 in light of Genesis 28:12 follows to illustrate how themes like the ladder, Jacob or Bethel that are not mentioned in 1:51, are introduced in expositions of the text. Such interpretations are shown to be problematic and indeed over-interpretations of what John 1:51 wants to communicate. Some practical methodological suggestions are then made.

\section{Inleiding}

Die Johannesevangelie is reeds vanaf die tyd van die vroeë kerkvader, Klemens van Alexandria (ongeveer 150-215 nC.), bekend as die 'geestelike Evangelie', veral vanweë die teologiese en simboliese aard van die Evangelie. Die ryk gebruik van simboliese taal het meermale tot 'n teologiese oorinterpretasie aanleiding gegee. Die probleemstelling wat in hierdie artikel aandag gaan ontvang, is die oorinterpretasie van tekste in gevalle waar daar moontlike verwysings na ander tekste is. Die spesifieke vraagstellings waarop gekonsentreer gaan word, is in hoeverre die intertekstuele verwysing na Genesis 28 (die Jakob-Bet-El-verhaal) die interpretasie van Johannes 1:51 interpretatief beïnvloed en of die interpretasies reg laat geskied aan die verstaan van 1:51. Aangesien 1:51 as sleutelteks in Johannes gereken word (Beasley-Murray 2002:30; Brown 1971:319; Schnackenburg 1968a:319), het die interpretasie van die teks konsekwensies vir die verstaan van die res van die Evangelie, veral vir die Christologie en engeleleer.

\section{Genesis 28 as interteks vir 1:51 Genesis 28:12 in 1:51?}

Die frase in Genesis 28:12 waarna daar in 1:51 verwys word, handel oor engele wat na die hemel opvaar en dan weer op die Seun van die Mens neerdaal. Sien die onderstaande tabel vir 'n vergelyking tussen die twee tekste (sien Tabel 1).

Die vergelyking toon dat die enigste raakpunt tussen die twee tekste die verwysing na die engele wat opvaar en neerdaal is. Die ooreenkoms in albei tekste van die onverwagte orde van die engele se aksies - eers opvaar en dan neerdaal - vorm een van die hoofargumente ten gunste van die intertekstuele konneksie tussen Genesis 28 en 1:51.

Waarop egter gelet moet word, is die groot verskil tussen die res van die twee kontekste. Die grootste hoeveelheid van die narratiewe gegewens uit Genesis 28:12 kom nie in 1:51 voor nie en word ook nie eers indirek na verwys nie. Daar is byvoorbeeld in 1:51 nie sprake van 'n leer, die aarde, 'n klip of Bet-El nie; daar word ook nie na 'n droom verwys nie; daar is ook geen stem van God of reaksie op die stem van God nie; en Jakob maak nie deel van die gebeure in 1:51 uit nie, terwyl die Seun van die Mens geen rol in Genesis 28:12 speel nie. ${ }^{2}$

1.Alle verdere verwysings na die Evangelie van Johannes sal slegs met hoofstukke en verse aangedui word.

2.Volgens Schnackenburg (1968a:320) is die verwysing na Genesis 28:12 in Johannes 1:51 'loose and free'. 
TABEL 1: Tekstuele vergelyking tussen Genesis 28:12 (LXX) en Johannes 1:51.

\begin{tabular}{|c|c|}
\hline Gen 28:12 (LXX)† & Johannes 1:51 \\
\hline \multicolumn{2}{|c|}{ 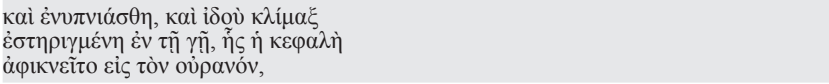 } \\
\hline & 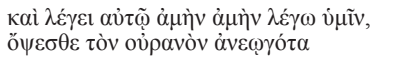 \\
\hline \multicolumn{2}{|c|}{ 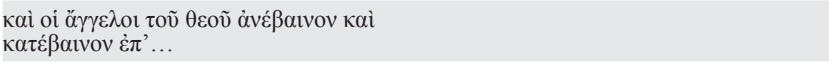 } \\
\hline \multirow[t]{2}{*}{ 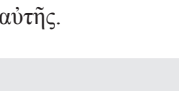 } & 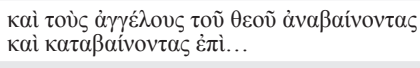 \\
\hline & 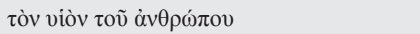 \\
\hline
\end{tabular}

$\dagger$ Dit is legitiem om die LXX teks te gebruik, aangesien die outeur van die Evangelie hoofsaaklik daarvan gebruik maak - vgl. Menken (1996).

Wat kan hieruit afgelei word? 'n Legitieme afleiding sou wees dat die outeur van 1:51 nie na die hele episode in Genesis 28 wil verwys nie, maar dat hy een van baie aspekte van die verhaal wil beklemtoon, naamlik die aksies van die engele. Die opmerking word ondersteun deur die feit dat Johannes $^{3}$ sy eie teks in 1:51 skep. ${ }^{4}$ Daar is gesien dat behalwe vir die bewegings van die engele niks anders uit die konteks van Genesis 28 in 1:51 opgeneem is nie. Aan die ander kant voeg Johannes weer verskeie elemente wat nie in Genesis 28 voorkom nie in sy kort segging, byvoorbeeld, hy maak 'n verwysing na die hemel wat geopen is en na die Seun van die Mens. Hierdie kombinasie van elemente kom nêrens anders in die bekende literatuur voor behalwe hier nie. Dit dui op die uniekheid van 1:51 waarin verskillende elemente in 'n nuwe kombinasie saamgevoeg word. Dit maak dit ook des te meer moontlik dat Johannes alleen maar een aspek uit Genesis 28:12 wou beklemtoon en nie in die eerste plek in gedagte gehad het om die hele konteks van leer, klip, droom, stem uit die hemel en Jakob of Bet-El met die verstaan van 1:51 te integreer nie.

Die punt word ook metodologies onderbou deur die insigte van intertekstualiteit wat ons van die kreatiwiteit van die proses waarin een teks met 'n ander teks intertekstueel in 'n interaktiewe proses verbind is, bewus gemaak het. Die proses veronderstel nie dat die bronteks in sy geheel in die nuwe teks opgeneem word nie, maar by wyse van integrasie word aspekte van die bronteks selektief en gedeeltelik in die nuwe teks opgeneem en inderdaad geherinterpreteer en nuut gesitueer. So funksioneer die bronteksverwysing binne die beperkings, eise en grense van die nuutgevormde teks waartoe dit natuurlik ook gedeeltelik bydra. Die vraag is wat die bronteks bydra tot die verstaan van die nuwe teks. ' $n$ Metodologiese eis is dus dat daar noukeurig gereflekteer word oor die bydrae van so 'n verwysing tot die interpretasie van die nuwe teks.

Uit die veronderstelde verwysing in 1:51 na Genesis 28:12 is dit duidelik dat drie konsepte van belang is: eerstens, die verwysing na engele van God; tweedens, die beweging van die engele van onder en terug na bo; en derdens, die beweging na of op ( $\dot{\varepsilon} \pi i ́)$ die Seun van die Mens.

3.'Johannes' is gerieflikerheidshalwe ' $n$ verwysing na die outeur(s) van die Evangelie, sonder om enige verdere verwysings rakende outeurskap.

4.Schnackenburg (1968a:320) merk op: 'If it is not an erratic block from another tradition which contained 'angelophanies', it must be taken as metaphor.' Sy onsekerheid stam daaruit dat daar nie in die res van die Evangelie weer na die engele se beweging verwys word nie. Brown (1971:88-89) is van mening dat Johannes 1:51 nie van die begin af deel van die konteks was nie, maar eerder in ' $n$ konteks tuishoort waar die parousia ter sprake was (vgl. ook Becker 1979:104; konteks tuishoort
Lindars 1987:119).

\section{Engele in Johannes 1:51 en Genesis 28:12}

Wat kan mens van die verwysing na die engele aflei? Sonder om in detail op die engeleleer ${ }^{5}$ in te gaan, is dit belangrik om tog daarop te let dat engele as hemelse figure ten tye van die Nuwe Testament in die algemeen as diensknegte van God gesien is. Binne die engeleleer was God egter nie die enigste een met diensknegte nie, maar die bose het as groep 'n 'parallel' gevorm - daarom word van die 'engele van God' gepraat. $^{6}$

God se engele het nie 'n spesifieke of enkele taak gehad soos byvoorbeeld om boodskappe te dra of openbarings te maak wat hulle altyd moes uitvoer nie. Aanvanklik was die term

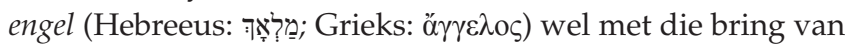
boodskappe geassosieer (Berlejung 2009:1165), maar met die ontwikkeling van monoteïsme het die funksie van die engele verbreed tot dié van diensknegte wat, na gelang van die vereistes van God, 'n verskeidenheid take kon verrig (Meier 2009:1167; Di Tommaso 2009:1173-1177; Tuschling 2007). Di Tommaso (2007:1173) noem dat veral in die na-eksiliese periode die idee van die transendensie van die monoteïstiese God, asook 'the corresponding sense of his disassociation from the everyday process of the world', die idee van hemelwesens wat as hemelse diensknegte opgetree het, bevorder het. As God se verteenwoordigers op aarde het hulle gedoen wat God wou hê hulle moes doen en dit kon 'n verskeidenheid dinge insluit. Dit is dus belangrik om in die lig hiervan nie aan te neem dat engele, ongeag die konteks, altyd byvoorbeeld boodskappe bring of as openbaarders optree nie. Die konteks moet in die eerste plek bepaal wat die funksie van die engele in enige gegewe situasie is - ook in 1:51.

\section{Wat is die funksie van die engele in Johannes $1: 51$ ?}

Die engele beweeg alleen maar van onder na die geopende hemel en terug. Meer as dit doen hulle nie. Kontekstueel lê die interpretatiewe sleutel in die beweging se betekenis, veral omdat dit ook die aspek is wat na Genesis 28:12 verwys. Interessant genoeg is dit ook al wat die engele in Genesis 28:10-13 doen: hulle beweeg op en af (op 'n leer). Direk na die verwysing na die engele gaan die verhaal van Genesis 28 voort met die opmerking dat die Here (nie die engele nie) op

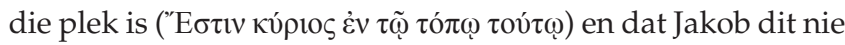
geweet het nie. Hy maak dan die gevolgtrekking dat dit die huis van die Here is asook die poort na die hemel (aṽ $\tau \eta \dot{\eta} \pi v ́ \lambda \eta$

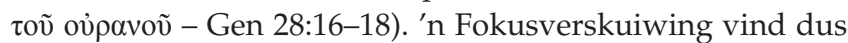
plaas.

Enkele aspekte uit die Genesisverhaal is belangrik om op te let. Daar is 'n leer tussen die hemel en die aarde waarop die engele op en af klim. Hulle merk dus die plek waar God verwag kan word en hulle kan dit doen, want hulle word

5.Vergelyk Tuschling (2007) en die verskillende artikels in Reiterer, Nicklas en Schöpflin (2007). Vergelyk ook, Hogeterp (2007:377-392), Kurek-Chomycz en Bieringer (2007:329ff.), Schreiber (2007:437ff.) en Wassen (2007:499-523).

6.Soos in Genesis 28:12 word die engele as engele van God in Johannes 1:51 geïdentifiseer. ' $n$ Rede mag wees om die engele van God van ander geestelike wesens, byvoorbeeld die duiwel te onderskei. Laasgenoemde word ook in die Johannesevangelie vermeld (vgl. Van der Watt 2011:185-204). 
assosiatief met Hom verbind as sy diensknegte wat vir Hom gereed staan. Waar die engele van God is, is daar ook die verwagting van die teenwoordigheid van God. Sodra die engele genoem word, verskyn die Here ook. Die engele is dus nie die goddelike teenwoordigheid nie, maar skep alleen die verwagting van die goddelike teenwoordigheid. Hulle dui op die goddelike teenwoordigheid. Hulle teenwoordigheid skep die verwagting van die teenwoordigheid van God. Daarom kon Jakob die stem wat hy gehoor het as die stem van die Here identifiseer. Die teenwoordigheid van die engele het daarop gedui.

Die verwysing in 1:51 sluit in alle waarskynlikheid by Genesis 28:12 aan. In 1:51 word ook alleen maar die beweging van die engele beklemtoon. Dit is die spesifieke aspek uit Genesis 28:12 wat Johannes wil beklemtoon. Dit lyk dus waarskynlik dat die beweging van die engele in 1:51 in aansluiting by Genesis 28:12 die locus van goddelike teenwoordigheid wil merk (Brown 1971:91; Groenewald 1980; Keener 2003:489; Schnackenburg 1968b:320). God se diensknegte is daar en daarom kan God ook daar verwag word. Kortom, die verwysing na die engele in 1:51 wil op simboliese wyse ${ }^{7}$ aandui dat waar die Seun van die Mens is, die goddelike teenwoordigheid verwag kan word. Meer as dit openbaar die engele nie en doen hulle ook nie.

Hierdie laaste opmerking oor die beperking van die funksionaliteit van die engele in die Evangelie word in die res van die Evangelie bevestig. Die woord ö $\gamma \gamma \varepsilon \lambda$ o $\varsigma$ word op nog twee plekke in die Evangelie gebruik, ${ }^{8}$ naamlik in 12:29 en 20:12. In 12:29 dink die mense dat hulle engele hoor praat, maar dit blyk dat hulle die stem van God foutiewelik met dié van engele verwar het - waarskynlik omdat hulle met die vooronderstelling gewerk het dat engele primêr openbaarders is. ${ }^{9}$ In Johannes vervul die engele egter nie hierdie rol nie. God praat hier, sonder bemiddeling, direk met Jesus. ${ }^{10}$ Met hierdie misverstand beklemtoon Johannes dat engele funksioneel nie meer openbaar nie, maar dat openbaring direk van die Vader en die Seun kom. 'n Ander funksie van engele was dat indien mense nie die boodskap verstaan nie, engele dit gewoonlik uitgelê het. In hierdie geval (12:29) verstaan die mense ook nie die boodskap nie, maar dit is Jesus en nie die engele nie wat dit uitlê. So vervang die werklike goddelike openbaring deur Jesus die openbaringsfunksie van die engele. Die tema kom herhaaldelik in die Evangelie voor, byvoorbeeld dat die dissipels vryelik met die Vader kan praat sonder die bemiddeling van engele $(16: 23,26)$, of dat die Gees hulle in die waarheid sal lei (16:13).

Die ander verwysing na engele in die Evangelie is in 20:12-13. Dit is 'n komplekse narratief waarop nie hier in detail

7.Brown (1971:320) noem die verwysing na die engele 'n metafoor

8.Die verwysing in 5:4 word nie hier in aanmerking geneem nie, aangesien dit volgens tekskritiese oorwegings nie deel van die oorspronklike teks was nie (vgl. Hodges 1979:25-39).

9.Dat die stem van God met donder geassosieer word, is duidelik uit gedeeltes soos 2 Sameul 22:14, Job 37:4, Psalm 18:7-16, 29:3, Jeremia 10:13, Openbaring 8:5, 11:19, en 16:18 (vgl. Beasley-Murray 2002:212; Keener 2003:877).

10.Vergelyk ook Keener (2003:876) se opmerkings oor die misverstand van die skare (sien ook Newman \& Nida 1993:411). ingegaan kan word nie (vgl. Van der Watt 2011:185-204). Wanneer Maria in die graf inkyk, sien sy twee engele wat in die graf op die plek sit waar Jesus se liggaam gelê het. Waarom hulle spesifiek sit waar Jesus se voete en kop onderskeidelik was, bly steeds 'n onopgeloste raaisel met uiteenlopende verklarings. ${ }^{11}$ Sommige oplossings argumenteer dat die engele alleen die plek waar die liggaam gelê het, aandui of merk. Dit sou kon wees omdat die grotgrafte gewoonlik plek vir meer as een persoon gehad het, en Maria miskien nie kon weet waar Jesus gelê het nie. Op hierdie manier kon sy sien dat Jesus se liggaam nie meer op die plek is waar dit was nie. 'n Ander verklaring is dat die engele op goddelike teenwoordigheid en aktiwiteit dui. Hulle self is nie God nie, maar as diensknegte van God dui hulle aan dat God daar werksaam was. Daarom is die graf leeg (Beasley-Murray 2002:374). Dit is nodig omdat daar ook ander moontlikhede was waarom die graf leeg was, byvoorbeeld dat die liggame weggeneem is. Wat ook al daar gebeur het, God was daar in aksie. Dit sou dan die opmerking in 1:51 eggo, naamlik dat God by die Seun van die Mens betrokke is - in hierdie geval deur sy opstanding uit die dood (vgl. 10:17-18). Opvallend is ook die verdere aksie van die engele in die graf. Hulle vra aan Maria waarom sy die lewende onder die dooies soek. Hulle openbaar niks, maar deur hulle vraag rig hulle Maria se aandag na buite waar sy Jesus vind. Dit is dan Jesus wat aan haar openbaar dat Hy opgestaan het. Weereens speel die engele alleen maar 'n verwysende rol. Op hierdie wyse word die engele se funksies aansienlik beperk (vgl. Van der Watt 2011:203-204).

\section{'Op' die Seun van die Mens of 'na' Hom?}

Die derde aspek van die verwysing is dat die engele op (غ̇лí) die Seun van die Mens opvaar en neerdaal. Met die eerste oogopslag lyk dit nie na 'n sentraal-belangrike aspek van die interpretasie van die gedeelte nie, maar by verdere oorweging word die belang van die woord غ̇ंí tog duidelik. In die interpretasiegeskiedenis word telkens gevra waarna die 'op'

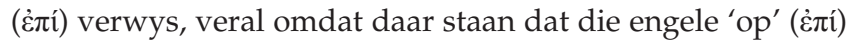
die Seun van die Mens opvaar en afdaal. Hoe moet mens jou dit voorstel?

Die semantiek van die woord غ̇ंí is kompleks en kan op verskillende maniere verstaan word.12 Daar kan veral op twee leksikografiese betekenisse gelet word: Eerstens, die woord غ̇ंí kan 'n plek, ruimte of spasie aandui wat die vraag beantwoord: 'waar ...?' (Arndt, Danker \& Bauer 2000:364; Louw \& Nida 1996) Hierdie betekenismoontlikheid sou op grond van die verwysing na Genesis 28:12 غ̇ंí daarop kon dui dat die engele op die Seun van die Mens klim asof hy 'n leer of reusepersoon sou wees. Tweedens, die gebruik van غ̇ंí met die akkusatief kan ook na beweging in die rigting van of

11.Beasley-Murray (2002:374) se verklaring rakende die plek waar die engele sit, lui so: 'Their position in the tomb... is a reminder of the silent testimony of the grave clothes, but of another order; it witnesses that God, not robbers, has taken Jesus, for a purpose yet to be revealed.' Sy uiteensetting is nie oortuigend nie, aangesien dit nie verklaar waarom die engele op die spesifieke plekke sit nie. Dat die teenwoordigheid van die engele egter getuig van God, is wel korrek.

12.Pistorius (1947:19) meen dat die interpretasie van غ̇лí as 'op' nie sin maak nie, veral omdat die engele ook opvaar. Hy sien dit as 'n genitief van doel en vertaal dit as 'ter wille van'. Die engele beweeg dus op en af ter wille van Jesus. 
kontak met 'n doel of objek verwys. Die doel kan selfs bereik word, naamlik, 'on or upon someone or something' of dit kan op die nabyheid van iemand dui (Arndt et al. 2000:364; vgl. 19:33). ${ }^{13}$ Ten opsigte van Genesis 28:12 merk Michaels (2011:41) en ander op dat 'the original Hebrew is ambiguous and some of the rabbis read the text as "on him" (i.e., on Jacob)'. Dit kan ook die geval in 1:51 wees, soos Michaels (2011:41) opmerk: 'The phrase in John's Gospel uses the Greek preposition غ̇лi with the accusative case to denote motion toward an object.' Volgens hierdie gebruik is die Seun van die Mens op aarde en die engele beweeg na Hom toe en weg van Hom af as doel of punt van hulle beweging (Brown 1971:90). Met werkwoorde van beweging dui غ̇ंí in elk geval nie 'n rusplek aan nie. Die engele doen niks by die plek nie, maar beweeg alleen daarnatoe en weg van daar af. Hulle merk die plek ván waar en waarná die beweging plaasvind (Lenski 1961:ad loc.). Dit kom nooit tot rus nie. Die Seun vervul nie die funksie van die leer nie, maar die plek waarheen en van waar die beweging plaasvind (Michaels 2011:44).

Aangesien die beeld van die engele se beweging in 1:51 'siklies' is (hulle beweeg van onder na bo en van bo na onder en van onder na bo, ens.) en hulle funksie is om goddelike teenwoordigheid te suggereer, is die tweede moontlikheid hierbo genoem die mees waarskynlike. In die lig van die voorafgaande argumentasies kan die gevolgtrekking gemaak word dat die engele die teenwoordigheid en verwagte plek van goddelike teenwoordigheid aandui. Die goddelike teenwoordigheid is (by) Jesus, die Seun van die Mens.

\section{'n Dwarssnit deur die interpretasiegeskiedenis van 1:51 in die lig van Genesis 28:12}

Beweeg ons nou egter na die interpretasiegeskiedenis van die gedeelte, tree 'n heel ander 'prentjie' van wat 1:51 wil kommunikeer na vore. Die 'prentjie' word ryklik deur al die fasette van die verhaal van Genesis 28 uitborduur met die suggestie dat 1:51 juis dít wil kommunikeer. Met behulp van enkele voorbeelde gaan nou geillustreer word hoe 1:51 dikwels in die lig van Genesis 28 interpretatief 'uitborduur' word. ${ }^{14}$

\section{Jakob se leer in 1:51}

Hoewel daar nie van 'n leer in 1:51 sprake is nie, kom verwysings na 'n leer baie algemeen in die interpretasie van die gedeelte voor. Veral die gebruik van die 'op' (غ̇ंí) gee aanleiding hiertoe. In Genesis 28:12 verwys die 'op dit' ( $\dot{\varepsilon} \pi^{\prime}$

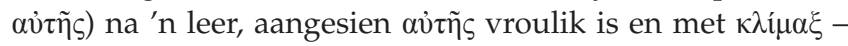
ook vroulik - korrespondeer. Die engele klim dus op en af op

13.Die moontlike gebruike van غ̇лí, byvoorbeeld om outoriteit oor iemand te hê, of wetlike prosedures teen iemand in te stel, of om vyandig teenoor iemand te wees, hoef vanweë kontekstuele oorwegings nie hier oorweeg te word nie.

14.Twee opmerkings is eers nodig: Eerstens, wat hier volg is alleen maar ' $n$ dwarssnit van wat in die navorsing beskikbaar is en maak nie aanspraak op volledigheid nie. Die doel van die kort oorsig is alleen maar illustratief. Ten tweede, wat in die dwarssnit aangebied word, is' $n$ sintese van materiaal rakende die interpretasie van 1:51. Die doel is nie om spesifieke outeurs te bespreek nie, maar om tendense in die interpretasie aan te dui. As meer spesifieke inligting oor spesifieke outeurs die interpretasie aan te dui. As meer spesifieke inligting
benodig word, moet die outeurs self geraadpleeg word. 'n leer. Op grond hiervan word geargumenteer dat daar ook 'n leer in 1:51 moet wees, al is dit implisiet. Gegewe die feit dat die 'op' na die Seun van die Mens verwys, word die idee van die leer dus aan hom verbind. In 1:51 is daar geen aanduiding van hoe die verhouding tussen die engele, die Seun en die fiktiewe leer gevisualiseer moet word nie. Gevolglik loop die voorstelle wyd uiteen - natuurlik met verskillende grade van verbeelding. ${ }^{15}$

Newman en Nida (1993:52) beweer dat die 'Son of Man takes the place of Jacob's ladder'. Jesus verbind die hemel en aarde soos die leer dit in die Jakobverhaal gedoen het en kan daarom die hemelse op aarde openbaar (Van Houwelingen 2007:77). ${ }^{16}$ 'n Alternatief is dat die Seun van die Mens die leer vervang 'as God's link with earth (cf. Dan. 7:13; Matt. 26-64)' (Blum 1985:2276-2278), of in die woorde van Barrett (1978:187): 'For the ladder John substitutes the Son of man'. Robertson (1916:49-51) meen 'He is able to be a "Jacob's ladder" for heaven and earth to meet in Him.' As variasie op hierdie tema word daar ook beweer dat op grond van die feit dat Natanael in 1:45-46 as 'n simbool vir Israel gelees kan word, ${ }^{17}$ Jesus die leer is wat Israel met die hemel verbind (vgl. ook Keener 2003:489-490). Daar is selfs opinies dat 'n reuse-Jesus bedoel word wat tot in die hemel reik. As anti-tipe van die leer klim die engele dan op Jesus op en af (Pink 1923-1945:74). ${ }^{18}$

Binne hierdie kader is daar ook opinies dat, hoewel Jesus nie direk die leer van Jakob genoem word nie, Hy tog funksioneel hierdie rol speel deur die openbaring tussen hemel en aarde te bemiddel. Attridge (2010b:68) meen dat die Seun van die Mens 'functioning as' of 'soos' ('like' -2010c:81) Jakob se leer is. Hy (Attridge 2010a:14) merk verder op: 'At John 1:51, the Son of Man is not surrounded by angels, but, through an evocation of Jacob's ladder, he becomes a vehicle for their ascent and descent.'

Dan is daar ook opinies dat Jesus nie die leer is nie, maar dat spesifiek sy kruis die leer is. Brant (2011:54) redeneer byvoorbeeld dat 'the ladder alludes to but is not limited to the cross'. Knowles (2001:508) sluit daarby aan deur te beweer: 'It is Jesus on his cross who will be the bridge between earth and heaven.'

Bogenoemde uiteenlopende voorbeelde illustreer die probleem, naamlik die duidelike oorinterpretasie van 1:51 wat aspekte daar inlees wat nie deur die teks self gestel word nie. Wat meer is, is dat die identifisering van Jesus as die (openbarings-)leer tot interpretatiewe en teologiese probleme lei. Deur Jesus as die leer te sien, word Hy die 15.Vergelyk Brown (1971:90-91) vir die bespreking van verskeie moontlikhede.

16.Vir soortgelyke idees vergelyk ook Bruner (2012:116-117), Hindson en Kroll (1994:2079) en Wiersbe $(1996: 213,289)$ wat beweer dat 'Jesus is Jacob's Ladder on earth'. Die identifikasie van Jesus as die leer het 'n lang Wirkungsgeschichte (vgl. byvoorbeeld Calvyn \& Pringle 2010:80-81; Köstenberger 2004:99; Maurice 1857:55-56). Newman en Nida (1993:53) waarsku daarteen om Jesus as die 'reus' te sien waarop die engele op en af klim, maar herinner tog daaraan dat dit hier om simboliese taal gaan (vgl. ook Groenewald 1980:ad loc.)

17.Schnackenburg (1968a:ad loc.) spekuleer dat Natanael die Tora en profete, rabbiniese spekulasies, en so meer gelees het (vgl. ook Brown 1971:89-90).

18.Daar is verskillende variasies van die idee. Brown (1971:90) noem vroeë Christene soos Justinus Triphos (Ixxxvi.2) wat van mening was dat Jesus op die leer was en dat die engele op Hom geklim het. 
objek waar(op) die engele hulle aktiwiteite uitoefen. In dié sin 'dien' Hy dan die engele en word die engele in fokus geplaas. Dit gaan direk teen die engeleleer en Christologie van die Evangelie in.

Die feit dat dit nie die leer is wat in Genesis 28 die basiese openbaringsfunksie vergestalt nie, maar God uit die hemel, bly ook buite oorweging. Om aan die leer openbaringskwaliteite toe te ken, is ' $n$ misinterpretasie van Genesis 28 sowel as 1:51. Daarbenewens word die feit misken dat die leer nie in 1:51 genoem word nie en ook nie nodig is nie (vgl. Carson 1991:162-164; Haenchen 1984:166). Hengstenberg (1865:115-116; vgl. ook Kerr 2002) het in 1865 reeds genoem dat aangesien die leer nie genoem word nie, 'it has no independent significance'.

\section{Nog enkele voorbeelde: Jesus as die nuwe Bet-El, of Jakob}

Op grond van die verwysing na Genesis 28 in 1:51 word Jesus deur sommige as "the "new Bethel," the place where God is revealed' gesien (Köstenberger 2004). ${ }^{19}$ Köstenberger (2004) beweer:

The Son of Man of 1:51 is the incarnate Word of 1:14, and both titles anticipate 2:14-22 and 4:19-24, where the Johannine Christological motif of Jesus' replacement/fulfillment of sacred space emerges. (p. 99)

So is die verband tussen die 'huis van God' (Bet-El) en Jesus vir hom duidelik gelê.

Jesus word ook op grond van die sogenaamde verband tussen Genesis 28 en 1:51 met Jakob geassosieer. Carson (1991:162-164) meen dat die Seun van die Mens in 1:51 met Jakob in Genesis 28 in verband gebring moet word, aangesien die engele op Jakob neergedaal het. Michaels (2011:41) formuleer die gedagte so: 'The Son of Man does not correspond to the stairway in Jacob's vision, but to Jacob himself at the bottom.' Op grond van die vergelyking tussen die twee relevante tekste, meen Köstenberger (2004:99) verder dat Jesus die woord van God soos Jakob gehoor het en daarom ook God se boodskap kan kommunikeer. Weens die kontras in status tussen Jesus en Jakob redeneer Köstenberger (2004:86) verder dat die woorde van 1:51 wil kommunikeer dat Jesus, 'will be the place of much greater divine revelation than that given at previous occasions ... Jesus is the very culmination of God's revelatory expressions' (vgl. ook Ellis 1984:38).

Hierdie interpretasies kan uiteindelik oploop tot breë interpretasies wat uiteenlopende sake insluit soos blyk uit die mening van Beasley-Murray (2002), gebaseer op die verband tussen Genesis 28 en 1:51:

Jacob's dream is clearly in the foreground, but there are reminiscences of the baptism of Jesus, possibly of his temptation, and of the eschatological and apocalyptic picture language used

19.Köstenberger (2004.99) formuleer dit soos volg. "The son of Man of 1.51 is the incarnate Word of 1:14, and both titles anticipate 2:14-22 and 4:19-24, where the Johannine Christological motif of Jesus' replacement/fulfillment of sacred space Johannine Christological motif of Jesus' replacement/fulfillment of sacred space
emerges.' So ook Blum (1985:2278) wat van 'God's dwelling place' praat (vgl. ook Brown 1971:320; Haenchen 1984:166). of the Son of Man, such as appears in the synoptic Gospels. (p. 28; vgl. ook Brown 1971:321; Schnackenburg 1968a:321)

Samevattend sou beweer kan word dat die meeste van bogenoemde voorbeelde die grense wat deur die teks self gestel is (vergelyk die eerste deel), oorskry en dus oorinterpretasie van die teks verteenwoordig.

\section{Enkele konklusies}

Die kontras tussen die 'close reading' van 1:51 en die verskillende interpretasies wat Genesis 28 gebruik om die betekenis van 1:51 op allerlei manier te verruim (sien hierbo), illustreer die probleem van intertekstuele lees van tekste. Die vraag bly altyd wat en hoeveel uit die bronteks(te) na die nuwe teks oorgedra mag word en hoe die nuwe teks die verwysings integreer ten einde 'n nuwe betekenis te vorm. Uit die voorbeelde hierbo het die gevare van oorinterpretasie duidelik geword. In die meeste gevalle is sake uit Genesis 28 wat nie eksplisiet of eers implisiet in 1:51 genoem word nie, in die interpretasie gebruik om die betekenis van 1:51 te verryk. Metodologies is dit problematies, veral as gesuggereer word dat die interpretasies die bedoeling of betekenis van 1:51 verwoord. Die interpretasie van ' $n$ teks moet aan die vereistes en grense wat deur die teks self gestel word, georiënteer word. Enkele metodologiese opmerkings in die verband kan op grond van bogenoemde analise gemaak word.

Die noukeurige lees van tekste wat die vereistes en grense wat deur die teks self gesuggereer word respekteer, behoort as die basiese vertrekpunt in die lees van antieke tekste te dien. Die veronderstelling is dat die teks self eers selfstandig aan die woord moet kom, waarna dit hermeneuties getrou binne ander en breër interpretasieraamwerke betrek word.

Eie persepsies moet voordurend aan die eise van die teks self getoets word. Om aan te neem engele is openbaringsfigure en dit dan so in 1:51 in te lees, lei tot presies die teenoorgestelde konklusie as wat die teks van 1:51 beoog. In Johannes word die openbaringsfunksie van die engele juis gedegradeer ten gunste van Jesus se funksie as die Openbaarder, die Woord van God. Voordat woorde, soos byvoorbeeld engele, dus met betekenis gevul word, moet die direkte kontekstuele konteks van 'n betrokke gebruik eers deeglik vasgestel en die grense vir die aanwending van die woord bepaal word. Die gevaar om teologiese konstrukte in die teks in te lees, is ewe groot, maar is nie hier in enige detail onder die loep geneem nie. Dit kom in 1:51 veral na vore in die oorweging van die rol van dieSeun van die Mens en die wyse en aard van die openbaring wat aan 1:51 ten gronde lê. Die aspekte val buite die skopus van hierdie bespreking.

Met die gebruik van die woord engele is daar gesien dat die openbarende aktiwiteit van engele in die Evangelie beperk word. Hierdie paradigmatiese inligting is belangrik, maar moet oordeelkundig by die interpretasie van individuele tekste gebruik word. Individuele tekste kan ook unieke bydraes maak - daarom moet wat in die res van die boek voorkom met die nodige oordeel met dit wat in die individuele gedeelte staan, in verband gebring word. 
Intertekstuele prosesse lei tot die vorming van die 'nuwe tekste' (bv. 1:51). Soos blyk uit die bespreking van 1:51 is daar konsepte saamgevoeg wat nie elders in dieselfde kombinasie voorkom nie. Dit veronderstel inderdaad nuwe relasies tussen konsepte wat nuwe betekenis wil uitdruk. Elke konsepbydrae moet binne die grense van die groter geheel van die nuwe teks vasgestel word. In gevalle van verwysings na ander tekste, byvoorbeeld Genesis 28, moet noukeurig gelet word waarna daar in die nuwe teks verwys word, asook hoe die gegewens in die nuwe teks aangewend word. Grense moet respekteer en gekontroleer word - ook ten einde die semantiese bydrae wat die nuwe teks wil maak te respekteer en te beskerm.

Oorinterpretasie kom selfs in van die beste kommentare voor. Dit beteken dat uitsprake dus nie sonder meer van ander oorgeneem moet word nie, maar dat eksegetiese kontrole aan die hand van die eise wat die teks self stel, voortdurend nodig is.

Bogenoemde konklusies mag wel vanselfsprekend voorkom. Eweneens moet toegegee word dat in die hantering van die Johannese literatuur die eksegetiese aspekte meer as dikwels nie met erns bejeën word nie, soos bogenoemde bespreking van 1:51 duidelik illustreer. Dit wil voorkom of eksegete wat bewus is van die gevare van oorinterpretasie van antieke tekste en intertekstuele verwysings, tog meer as wat nodig is in die strik van oorinterpretasie trap. Die belang van hierdie artikel lê juis daarin om die probleem konkreet te illustreer en te maan teen oorinterpretasie van Johannes as 'spirituele evangelie'.

\section{Erkenning \\ Mededingende belange}

Die outeur verklaar dat hy geen finansiële of persoonlike verbintenis het met enige party wat hom nadelig of voordelig kon beïnvloed het in die skryf van hierdie artikel nie.

\section{Literatuurverwysings}

Attridge, H., 2010a, 'Johannine Christianity', in H. Attridge (ed.), Essays on John and Hebrews, p. 14, Mohr Siebeck, Tübingen.

Attridge, H., 2010b, 'Genre bending in the Fourth Gospel', in H. Attridge (ed.), Essays on John and Hebrews, p. 68, Mohr Siebeck, Tübingen.

Attridge, H., 2010c, 'The cubist principle in Johannine imagery: John and the reading of images in contemporary Platonism', in H. Attridge (ed.), Essays on John and Hebrews, p. 81, Mohr Siebeck, Tübingen.

Arndt, W., Danker, F.W., \& Bauer, W., 2000, A Greek-English lexicon of the New Testament and other early Christian literature, University of Chicago Press, Chicago. [BDAG].

Barrett, C.K., 1978, The Gospel according to St John, Society for Promoting Christian Knowledge, London.

Beasley-Murray, G.R., 2002, John, Word, Dallas.

Becker, J., 1979, Das Evangelium des Johannes. Kapitel 1-10, Echter-Verlag, Würzburg.

Berlejung, A., 2009, 'Angels', in H.-J. Klauck et al. (eds.), Encyclopedia for the Bible and its reception, vol. 1, pp. 1165-1167, De Gruyter, Berlin.
Blum, E.A., 1985, 'John', in J.F. Walvoord, \& R.B. Zuck (eds.), The Bible Knowledge Commentary: An Exposition of the Scriptures, vol. 2, pp. 2276-2278, Victor, Wheaton.

Brant, J-A., 2011, John, Baker Academic, Grand Rapids.

Brown, R.E., 1971, The Gospel according to John (i-xii), vol. 1, Geoffrey Chapman, London.

Bruner, F.D., 2012, The Gospel of John: A Commentary, Eerdmans, Grand Rapids.

Calvyn, J. \& Pringle, W., 2010, Commentary on the Gospel According to John, vol. 1, Logos Bible Software, Bellingham.

Carson, D.A., 1991, The Gospel According to John, Eerdmans, Grand Rapids.

Di Tommaso, L. 2009, 'Angels in Judaism', in H.-J. Klauck et al. (ed.), Encyclopedia for the Bible and its reception, vol. 1, pp. 1174-1177, De Gruyter, Berlin.

Ellis, P.F., 1984, The genius of John, Liturgical Press, Minnesota.

Groenewald, E.P., 1980, Die Evangelie van Johannes, NG Kerk-Uitgewers, Kaapstad.

Haenchen, E., 1984, John: A Commentary on the Gospel of John, Fortress Press, Philadelphia.

Hengstenberg, E.W., 1865, Commentary on the Gospel of St John, vol. 1, T\&T Clark, Edinburgh.

Hindson E.E. \& Kroll, W.M. (eds.), 1994, KJV Bible Commentary, Thomas Nelson, Nashville.

Hodges, Z.C., 1979, 'The angel at Bethesda - John 5:4', Bibliotheca Sacra 136, 25-39.

Hogeterp, A.L.A., 2007, 'Angels, the final age and 1-2 Corinthians in light of the Dead Sea Scrolls', in F.V. Reiterer, T. Nicklas \& K. Schöpflin (eds.), Angels: The concept of celestial beings - Origins, development and reception, pp. 377-392, De Gruyter, Berlin.

Keener, C.S., 2003, The Gospel of John, vol. 1-2, Hendrickson, Peabody.

Kerr, A.R., 2002, The temple of Jesus' body: The Temple theme in the Gospel of John, Sheffield Academic Press, Sheffield.

Knowles, A. (ed.), 2001, The Bible Guide, Augsburg, Minneapolis.

Köstenberger, A.J., 2004, John, Baker Academic, Grand Rapids.

Kurek-Chomycz, D.A. \& Bieringer, R., 2007, 'Guardians of the old at the dawn of the new. The role of angels according to the Pauline letters', in F.V. Reiterer, T. Nicklas \& K. Schöpflin (eds.), Angels: The concept of celestial beings - Origins, development and reception, pp. 325-355, De Gruyter, Berlin.

Lenski, R.C.H., 1961, The Interpretation of St. John's Gospel, Augsburg Publishing House, Minneapolis.

Lindars, B., 1987, The Gospel of John, Eerdmans, Grand Rapids.

Louw, J.P. \& Nida, E.A., 1996, Greek-English lexicon of the New Testament: Based on semantic domains, United Bible Societies, New York.

Maurice, F.D., 1857, The Gospel of St. John: A Series of Discourses, Macmillan, Cambridge.

Meier, S., 2009, 'Angels in the Old Testament', in H-J. Klauck et al. (ed.), Encyclopedia for the Bible and its reception, vol. 1, pp. 1167-1173, De Gruyter, Berlin.

Menken, M.J.J., 1996, Old Testament Quotations in the Fourth Gospel: Studies in Textual Form, Kok Pharos, Kampen.

Michaels, J.R., 2011, John, Baker Books, Grand Rapids.

Newman, B.M. \& Nida, E.A., 1993, A handbook on the Gospel of John, United Bible Societies, New York.

Pink, A.W., 1923-1945, Exposition of the Gospel of John, Bible Truth Depot, Swengel.

Pistorius, P.V., 1947, Die Evangelie van Johannes, Van Schaik, Pretoria.

Reiterer, F.V., Nicklas, T. \& Schöpflin, K., 2007, Angels: The concept of celestial beings - Origins, development and reception, De Gruyter, Berlin.

Robertson, A.T., 1916, The Divinity of Christ in the Gospel of John, Fleming H. Revell, Edinburgh.

Schnackenburg, R., 1968a, The Gospel according to St John, vol. 1, Burns \& Oats, London.

Schnackenburg, R., 1968b, The Gospel according to St John, vol. 3, Burns \& Oats, London.

Schreiber, S., 2007, 'The great opponent. The devil in early Jewish and formative Christian literature', in F.V. Reiterer, T. Nicklas \& K. Schöpflin (eds.), Angels: The concept of celestial beings-Origins, development and reception, pp. 437-457, De Gruyter, Berlin.

Tuschling, R.M.M., 2007, Angels and Orthodoxy, Mohr Siebeck, Tübingen.

Van der Watt, J.G., 2011, 'Angels in the Gospel according to John', Journal of Early Christian History 1(1), 185-204.

Van Houwelingen, P.H.R., 2007, Johannes, Kok, Kampen.

Wassen, C., 2007, 'Angels in the Dead Sea Scrolls', in F.V. Reiterer, T. Nicklas \& K. Schöpflin (eds.), Angels: The concept of celestial beings - Origins, development and reception, pp. 499-523, De Gruyter, Berlin.

Wiersbe, W.W., 1996, The Bible Exposition Commentary, vol. 1, Victor, Wheaton. 